\title{
Vertical position of dry mass and elemental concentrations in Pinus sylvestris L. canopy under the different ash-nitrogen treatments
}

\author{
Iveta Varnagiryte-Kabašinskiene ${ }^{(1-2)}$, Vidas Stakenas ${ }^{(1)}$, \\ Virgilijus Mikšys ${ }^{(1)}$, Audrius Kabašinskas ${ }^{(3)}$
}

Compensatory biofuel ash fertilisation is recommended for managed Pinus sylvestris $L$. forests growing on nutrients poor Arenosols in Lithuania. We conducted an experiment between 2002 and 2005, investigating the effects of biofuel ash and nitrogen fertilisation applied to Scots Pine stands on nutrient poor Arenosols. We studied the effects of three fertilization treatments (biofuel ash, nitrogen and ash applied together with nitrogen) on dry mass and concentrations of the main nutrients $(\mathrm{N}, \mathrm{P}, \mathrm{K}, \mathrm{Ca}$ and $\mathrm{Mg})$ and other elements $(\mathrm{Cu}, \mathrm{Zn}$, $\mathrm{Cd}, \mathrm{Cr}, \mathrm{Ni}$, and $\mathrm{Pb}$ ) in different compartments and layers of the canopy. The biofuel ash, nitrogen fertilizers and ash applied together with nitrogen led to heavier needles in the upper and middle layers of the canopy with less effect toward the canopy base. The complex ash plus nitrogen treatment gave the strongest significant response. All treatments resulted in an increase in dry mass, but not in the length of the current year needles. The additional input of nitrogen induced higher increase in dry mass compared to the changes of $\mathrm{N}$ concentration in the youngest needles. On the basis of the present study results, it can be concluded that the youngest needles produced new mass per amount of nitrogen more effectively compared to older needles.

Keywords: Pinus sylvestris, Biofuel Ash, Canopy, Biomass, Nutrients

\section{Introduction}

Biomass and nutrient allocation and partitioning in Scots pine (Pinus sylvestris L.) canopies can be influenced by a number of internal and external factors. Previous studies have reported that dry mass and element concentrations in needles depend on needle age, tree species, age and soil conditions (Helmisaari 1992, Mäkelä \& Albrektson 1992, Finér 1994, Nilsen \& Abrahamsen 2003). A number of researchers attempted to explain the gradients of various causal factors, including light and temperature conditions, the water status of foliage (Pearcy \& Sims 1994, Niinemets et al. 2007, Gebauer et al. 2011), photosynthetic capacity (Han et al. 2003, Marcelis \& Heuvelink 2007), needle anatomy (Richardson et al. 2001, Luk janova \& Mandre 2009) or the concentration of carbohydrates (Mandre et al. 1998). The nutrient uptake and translocation mechanisms in the canopies of conifers growing both naturally and under stress conditions have been explored in several studies (Helmisaari 1992, Finér 1994, Mandre 2009, Ots et al. 2009, Kuznetsova et al. 2011). Helmisaari (1992) found that the dry mass per needle is low in the lower part of the crown, possibly as a result of changes caused by light. Ots et al. (2009) reported that both the growth and dry mass of 100 needles were high in the upper layers of pine canopies. There were no significant differences in the nutrient concentrations between different crown layers (Helmisaari 1992, Ots et al. 2009). Several studies were conducted on alkalized soils in Estonia to investigate vertical gradients of mineral elements in the pine canopy (Mandre 2009, Ots et al. 2009). Mandre (2009) concluded that vertical gradients of elements and their ratios in pine canopies vary depending on the alkalization level of the soil.

Biofuel ash contains a variety of mineral elements and could be used as a soil alkalizing amendment (Bramryd \& Fransman 1995, Rumpf et al. 2001, Saarsalmi et al. 2001, 2004, Karltun et al. 2008, Ozolinčius et al. 2010). Several studies have described the role of ash or other alkalizing amendments on the nutrient status of Scots pine biomass (Saarsalmi et al. 2001, 2004, Ozolinčius et al. 2007b, 2007c, 2010, Varnagiryte-Kabašinskiene 2008, Ots et al. 2011), its anatomy or the morphology of the pine canopy (Lukjanova \& Mandre 2009, Lukjanova \& Mandre 2010). Together, these studies show that pure wood, biofuel ash or their admixture with nitrogen could increase nutrient concentrations in different compartments of the aboveground tree biomass. Eventually, this can lead to an increase in biomass (Ozolinčius et al. 2007b, 2007c, 2010), although such treatments do not always promote tree growth (Jacobson 2003,
(1) Institute of Forestry, Lithuanian Research Centre for Agriculture and Forestry, Liepu str. 1, Girionys, LT-53101, Kaunas district (Lithuania); (2) Aleksandras Stulginskis University, Studentu str. 11, LT53351 Akademija, Kaunas district (Lithuania); (3) Kaunas University of Technology, Studentu str. 50, LT-51368 Kaunas (Lithuania)

(a) Iveta Varnagiryte-Kabašinskiene (i.varnagiryte@mi.lt)

Received: May 07, 2014 - Accepted: Nov 22, 2014

Citation: Varnagiryte-Kabašinskiene I, Stakenas V, Mikšys V, Kabašinskas A, 2015. Vertical position of dry mass and elemental concentrations in Pinus sylvestris L. canopy under the different ash-nitrogen treatments. iForest 8: 838-845 [online 2015-0325] URL: http://www.sisef.it/iforest/ contents/?id=ifor1342-007

Communicated by: Matteo Garbarino

Mandre et al. 2004, Saarsalmi et al. 2004).

Our earlier findings from an integrated biofuel ash experiment conducted in Lithuania showed that the effect on forest soils, ground vegetation and trees was often considerable, and dependent on the dose applied and treatment specifics, i.e., pure ash or ash admixed with nitrogen (Ozolinčius et al. 2007a, 2007b, 2007c, 2010, Varnagiryte-Kabašinskiene 2008). Drawing on the aforementioned sources, higher ash doses increased the soil $\mathrm{pH}$ and the total number of microorganisms, and significantly reduced moss cover. It also changed the soil and vegetation chemistry, as additional inputs of nitrogen tended to increase tree growth.

Assuming that the canopy is sufficiently sensitive to any changes in soil nutrient status, we aimed to find a detail approach to measure the effect of biofuel ash and nitrogen on each layer of the tree canopy. Thus far, there has been little discussion of the canopies of Scots pine trees growing on nutrient poor Arenosols. According to the previous studies, the concentrations of elements in the assimilation organs of forest tree species are closely related to the specifics of the soil conditions (Bauer et al. 1997).

This paper compares the effects of different applications of biofuel ash, nitrogen and ash applied together with nitrogen on dry mass and the concentrations of the main nutrients in different compartments and layers of a Scots pine canopy.

\section{Materials and methods}

\section{Site description}

Investigations were conducted in the Ka- 
Tab. 1 - Main characteristics of the experimental plots before treatment. Values are given as the mean \pm standard error.

\begin{tabular}{|c|c|c|c|c|c|}
\hline Treatment & $\mathrm{N}$ trees $\mathrm{ha}^{-1}$ & $\begin{array}{l}\text { Volume } \\
\left(\mathbf{m}^{3} \mathbf{h a}^{-1}\right)\end{array}$ & $\begin{array}{c}\text { Basal area } \\
\left(\mathbf{m}^{2} \mathbf{h a}^{-1}\right)\end{array}$ & $\begin{array}{c}\text { Average } \\
\text { DBH (cm) }\end{array}$ & $\begin{array}{c}\text { Average } \\
\text { height (m) }\end{array}$ \\
\hline Control & $1674.0 \pm 39.1$ & $195.7 \pm 19.7$ & $26.9 \pm 2.3$ & $14.3 \pm 0.5$ & $14.8 \pm 0.2$ \\
\hline $5 \mathrm{tha}^{-1}$ ash & $1570.0 \pm 74.0$ & $159.7 \pm 17.6$ & $22.4 \pm 2.1$ & $13.4 \pm 0.3$ & $14.4 \pm 0.1$ \\
\hline $180 \mathrm{~kg} \mathrm{ha}^{-1} \mathrm{~N}$ & $1674.3 \pm 115.7$ & $170.2 \pm 16.8$ & $24.0 \pm 1.8$ & $13.6 \pm 0.8$ & $14.4 \pm 0.4$ \\
\hline $\begin{array}{l}\text { ( } 2.5 \mathrm{t} \mathrm{ash}+180 \mathrm{~kg} \\
\text { N) } \mathrm{ha}^{-1}\end{array}$ & $1467.0 \pm 179.6$ & $155.6 \pm 19.9$ & $21.8 \pm 2.1$ & $13.9 \pm 1.1$ & $14.5 \pm 0.5$ \\
\hline
\end{tabular}

čergine forest district of the Dubrava Experimental and Training Forest Enterprise in southwestern Lithuania $\left(54^{\circ} 55^{\prime} \mathrm{N}, 23^{\circ} 43^{\prime}\right.$ $\mathrm{S})$. The sample plots were selected in a Scots pine stand that was planted in 1964. The forest type was Pinetum vacciniosum, and the forest site type was $\mathrm{Nb}$ - oligotrophic mineral soil of a normal moisture regime, according to the Lithuanian classification (Vaičys et al. 2006). This forest type is common in Lithuania.

The initial planting density was around 8000 plants ha $^{-1}$. Two thinnings were performed in 26 and 33-year-old stands, and the stand density in 2002 was 1498 trees $^{-1} \mathrm{~h}^{-1}$ Detailed characteristics of the experimental plots are given in Tab. 1. The stand production class was determined to be $5.3 \mathrm{~m}^{3} \mathrm{ha}^{-1}$ per year.

The parent material in this study area was a glaciolacustrine plain (elevation 75-90 m a.s.1.) overlying glaciofluvial sand from the Riss-Wurm (Weichselian) glaciation. The soils were classified as well-drained Haplic Arenosols (Buivydaite et al. 2001, FAO/UN 2006).

The mean annual temperature was $6.5^{\circ} \mathrm{C}$, and the mean annual precipitation was 686 $\mathrm{mm}$. The $\mathrm{pH}_{\mathrm{CaCl} 2}$ was 3.5 in the $\mathrm{O}+\mathrm{E}$ horizon, and 4.3 in the mineral layers. The bottom vegetation layer was dominated by mosses, with the most common species being Pleurozium schreberi (Brid.) Mitt., Dicranum polysetum Sw., Dicranum scoparium Hedw. and Hylocomium splendens (Hedw.) Schimp.

\section{Biofuel ash characteristics and treatments}

The integrated field experiment of compen-

Tab. 2 - Chemical composition of forest biofuel ash applied in the field experiment.

\begin{tabular}{llc}
\hline Group & Element & Concentrations in ash \\
\hline Macronutrients $\left(\mathrm{g} \mathrm{kg}^{-1}\right)$ & Phosphorus & 2.15 \\
& Potassium & 5.29 \\
& Calcium & 72.0 \\
& Magnesium & 9.45 \\
\hline Micronutrients $\left(\mathrm{mg} \mathrm{kg}^{-1}\right)$ & Copper & 13.1 \\
& Zinc & 73.7 \\
\hline Heavy metals $\left(\mathrm{mg} \mathrm{kg}^{-1}\right)$ & Chromium & 9.51 \\
& Cadmium & 0.62 \\
& Lead & 4.53 \\
& Nickel & 8.05 \\
\hline
\end{tabular}

surements.

Tree sampling for biomass measurements was conducted during a non-vegetative period between 2004 and 2005. Canopy defoliation was assessed and canopy diameter was measured. Sample trees with marked north sides were cut. Living whorls were numbered from the top, and the canopy limit and the middle of the canopy were also marked. Tree height and annual height increment were measured, and sample branches were collected. The residual branches per each whorl were counted and weighed, and the middle branch was collected.

In the laboratory, the lengths of each sampled branch, the main branch axis and the increments of the leading shoots were measured. Each sampled living branch was divided into four compartments: (i) currentyear needles; (ii) one-year-old needles; (iii) older needles; and (iv) the branches and shoots without needles. All samples were dried at $70{ }^{\circ} \mathrm{C}$ for 48 hours and weighed. The samples of the current year foliage were sampled in detail: the masses of the needles and shoots, the total lengths of the shoots, the masses of 50 current-year needles, and the lengths of 20 needles were assessed.

For the chemical analyses, the foliage was sampled from five Scots pine trees of the Kraft class II in each plot during the dormancy period of 2004. The sampled current and one-year-old shoots with needles were taken from the upper third (5- $7^{\text {th }}$ whorls) of the canopy. The needles were removed from the shoots and grouped into current-year and one-year-old needles. Before analysis, equal quantities of each of the five samples from each plot were pooled to form a composite sample and were dried at $60{ }^{\circ} \mathrm{C}$ for 24 hours (Rautio et al. 2010). Total $\mathrm{N}$ was analysed by the Kjeldahl method, total $\mathrm{P}$ was determined by the V-Mo-blue colorimetric method, $\mathrm{K}$ by flame photometry, and $\mathrm{Ca}$ and $\mathrm{Mg}$ using the flame atomic adsorption spectroscopy (AAS).

\section{Calculations and statistical analysis}

The masses (in grams) of the sampled and dried shoots and branches with needles were multiplied by the number of branches per whorl. The biomass of each compartment and layer, as well as that of the total canopy, were calculated by summing the masses of each whorl. For further calculations, the canopy was divided into three equal horizontal layers that were numbered from the top to the canopy base, i.e., the upper layer of canopy included the whorls numbered from 1 to 5 , the middle layer the whorls numbered 6-10, and the lower layer whorls 11-15.

Departure from the normal distribution of the variables was checked by Lilliefors and Kolmogorov-Smirnov tests. However, the normality hypothesis was rejected for all observed variables $(\alpha=0.05)$. 
The Kruskal-Wallis analysis of variance (ANOVA) test was used to ascertain significant differences in the dry masses and nutrient concentrations between different treatments (4 groups: control, pure ash, pure nitrogen and ash plus nitrogen). The aforementioned test was taken as a nonparametric alternative to between-groups one-way ANOVA, as the data were non-normally distributed. Throughout the study, the means are presented with the standard errors of the mean $( \pm \mathrm{SE})$. Statistical analyses were conducted using the software package STATISTICA 7.0 ${ }^{\circledR}$ (StatSoft, Tulsa, OK, USA) and a level of significance of $\alpha=0.05$ was chosen in all cases.

\section{Results}

\section{Response of dry masses to different treatments}

The application of pure ash, nitrogen and ash plus nitrogen in nutrient poor, sandy soils positively affected the growth of different canopy compartments. However, the responses of the different treatments were inconsistent. The only significant effect was that the dry mass of the needles increased by 1.4-fold after the application of the combined treatment, compared with the control (data not shown). The application of pure ash and nitrogen increased the dry mass of needles by 0.4 and $1.1 \mathrm{~kg}$ per tree, respectively. There was no significant difference in the total dry masses of the canopy and branches between the control and other treatments.

The previously mentioned differences were gradually revealed when the treatment effects were analyzed separately on the current, one-year-old and older needles and shoots (data not shown). The application of ash along with nitrogen significantly increa- sed the dry mass of current and one-year-old needles by 1.5-1.6-fold, and it increased the dry mass of current year shoots by 2 -fold. In the plot treated with pure nitrogen, the dry masses of the current and one-year old needles also increased by 1.4-1.6-fold compared with the control, although only the increase in the mass of the one-year old needles was statistically significant $(p<0.05)$.

The highest significant increase of current and one-year old needles mass was found in the middle canopy layer (Tab. 3). The dry mass of current-year needles and one-yearold needs increased significantly (1.7- and 2fold, respectively). Despite the fact that the dry masses of current and one-year-old needles increased by 1.8-2-fold in the upper canopy layer, no statistically significant effect of the ash plus nitrogen application was found. The effect of the ash plus nitrogen treatment on both current and one-year old shoots was less pronounced when compared with the changes in the needles. The currentyear shoots were significantly (1.5-1.6-fold) heavier in the upper and middle layers of the canopy.

The application of $5 \mathrm{t} \mathrm{ha}^{-1}$ of ash did not significantly increase the dry masses of current and one-year-old needles in the upper layer of the canopy (Tab. 3). Slightly heavier needles and current-year shoots in the upper and middle canopy layers were produced after the application of pure nitrogen.

\section{Response of some morphometric parameters in different whorls of the canopy}

The results obtained from the analysis of the dry mass of current-year needles and shoots, aiming to estimate the changes in each whorl of the Scots pine canopy, are shown in Fig. 1. The overall visual assessment of the data in Fig. 1 shows that the highest upturn of the dry mass occurred in the middle part of the canopy. Moving to a smaller scale, the statistically significant ash plus nitrogen effect on the dry mass of the current-year needles was in the top of the Scots pine canopy ( $1^{\text {st }}$ whorl), as well as in the $6^{\text {th }}$ and $7^{\text {th }}$ whorls (Fig. 1a). Similarly, the dry mass of current-year shoots significantly increased in the same whorls of the canopy (Fig. 1b).

Relative to the control $(100 \%)$, the dry masses of current year needles (Fig. 1a) and shoots (Fig. 1b) in the upper whorls, i.e., starting from the top up to the $8-9^{\text {th }}$ whorls, increased by more than $50 \%$ in the ash plus nitrogen treatment. This increasing tendency consistently descended as one moved towards the canopy base. The masses of oneyear old needles and shoots in each whorl showed a similar tendency (data not shown). The main significant changes resulting from the ash plus nitrogen treatment were recorded in the top $(p=0.001)$ and $6-8^{\text {th }}(p=0.03)$ whorls of the canopy. The increase in dry mass resulting from the ash plus nitrogen treatment was more pronounced for needles than shoots.

According to the overall data assessment, the mass of 50 needles was greater in the pine top, and showed a descending trend towards the canopy base (Fig. 2). Biofuel ash and nitrogen treatments increased the dry mass of pine needles compared with the control in almost all canopy whorls (Fig. 2b). The effect of pure wood ash was lower than the nitrogen treatments, or equal to the pure nitrogen effect in the pine top. Similar to the previously examined cases, the ash plus nitrogen application gave the strongest significant response $(\mathrm{p}<0.05)$ in almost all canopies, except for the lowest whorls.

The results of the needle length analyses are presented in Fig. 3. However, in our

Tab. 3 - Dry mass (g) of current and one-year old needles and shoots in three different layers of canopy 2 years after treatment. Values are given as the mean \pm SE $(n=9)$. Different letters indicate statistically significant differences (Kruskal-Wallis ANOVA) in dry mass between treatments $(\mathrm{p}<0.05)$.

\begin{tabular}{|c|c|c|c|c|}
\hline \multirow{2}{*}{ Needles/Shoots } & \multirow{2}{*}{ Treatment } & \multicolumn{3}{|c|}{ Canopy layer } \\
\hline & & Upper layer & Middle layer & Lower layer \\
\hline \multirow[t]{4}{*}{ current year needles } & Control & $309.49 \pm 35.34^{\mathrm{a}}$ & $707.48 \pm 72.71^{\mathrm{a}}$ & $295.06 \pm 33.14^{\mathrm{a}}$ \\
\hline & $5 \mathrm{t} \mathrm{ash} \mathrm{ha}^{-1}$ & $465.70 \pm 56.76^{\mathrm{a}}$ & $863.94 \pm 112.76^{a}$ & $242.23 \pm 36.27^{\mathrm{a}}$ \\
\hline & $180 \mathrm{~kg} \mathrm{~N} \mathrm{ha}^{-1}$ & $438.02 \pm 73.87^{\mathrm{a}}$ & $951.33 \pm 75.05^{\mathrm{a}}$ & $385.35 \pm 74.55^{\mathrm{a}}$ \\
\hline & $(2.5 \mathrm{t}$ ash $+180 \mathrm{~kg} \mathrm{~N}) \mathrm{ha}^{-1}$ & $548.86 \pm 71.91^{a}$ & $1206.81 \pm 104.04^{b}$ & $340.62 \pm 58.96^{\mathrm{a}}$ \\
\hline \multirow[t]{4}{*}{ one-year old needles } & Control & $97.00 \pm 11.16^{\mathrm{a}}$ & $198.46 \pm 29.30^{\mathrm{a}}$ & $86.96 \pm 18.48^{a}$ \\
\hline & $5 \mathrm{t}$ ash ha-1 & $157.04 \pm 15.45^{\mathrm{a}}$ & $251.10 \pm 34.28^{a b}$ & $76.90 \pm 14.58^{a}$ \\
\hline & $180 \mathrm{~kg} \mathrm{~N} \mathrm{ha}^{-1}$ & $163.93 \pm 26.58^{a}$ & $303.51 \pm 38.87^{\mathrm{a}}$ & $146.91 \pm 33.91^{a}$ \\
\hline & $(2.5 \mathrm{t}$ ash $+180 \mathrm{~kg} \mathrm{~N}) \mathrm{ha}^{-1}$ & $189.48 \pm 30.60^{\mathrm{a}}$ & $392.32 \pm 47.24^{b}$ & $120.34 \pm 24.61^{a}$ \\
\hline \multirow[t]{4}{*}{ current year shoots } & Control & $257.75 \pm 42.80^{\mathrm{a}}$ & $754.96 \pm 91.16^{\mathrm{a}}$ & $348.79 \pm 43.86^{\mathrm{a}}$ \\
\hline & $5 \mathrm{t}$ ash ha ${ }^{-1}$ & $320.21 \pm 56.87^{\mathrm{a}}$ & $799.66 \pm 98.57^{\mathrm{a}}$ & $290.04 \pm 55.91^{a}$ \\
\hline & $180 \mathrm{~kg} \mathrm{~N} \mathrm{ha}^{-1}$ & $306.48 \pm 38.17^{\mathrm{a}}$ & $959.49 \pm 42.96^{\mathrm{a}}$ & $472.86 \pm 86.87^{a}$ \\
\hline & $(2.5 \mathrm{t}$ ash $+180 \mathrm{~kg} \mathrm{~N}) \mathrm{ha}^{-1}$ & $387.00 \pm 66.74^{b}$ & $1189.73 \pm 108.16^{b}$ & $465.12 \pm 86.97^{\mathrm{a}}$ \\
\hline \multirow[t]{4}{*}{ one-year old shoots } & Control & $126.06 \pm 19.85^{a}$ & $256.39 \pm 35.37^{\mathrm{a}}$ & $74.09 \pm 10.44^{a}$ \\
\hline & $5 \mathrm{t}$ ash ha $\mathrm{ha}^{-1}$ & $170.57 \pm 27.67^{\mathrm{a}}$ & $251.55 \pm 46.46^{\mathrm{a}}$ & $82.77 \pm 11.48^{a}$ \\
\hline & $180 \mathrm{~kg} \mathrm{~N} \mathrm{ha}^{-1}$ & $165.72 \pm 24.27^{\mathrm{a}}$ & $296.63 \pm 21.04^{\mathrm{a}}$ & $122.02 \pm 24.34^{\mathrm{a}}$ \\
\hline & $(2.5 \mathrm{t}$ ash $+180 \mathrm{~kg} \mathrm{~N}) \mathrm{ha}^{-1}$ & $196.30 \pm 37.10^{\mathrm{a}}$ & $369.12 \pm 44.45^{\mathrm{a}}$ & $117.80 \pm 26.17^{\mathrm{a}}$ \\
\hline
\end{tabular}




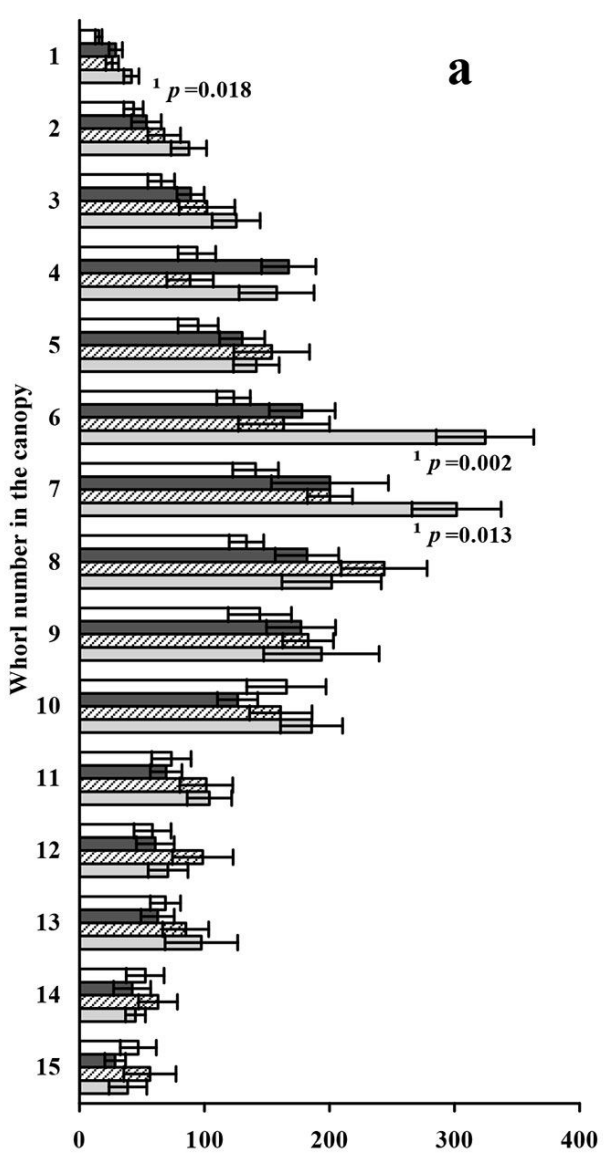

Dry mass of current year needles, g

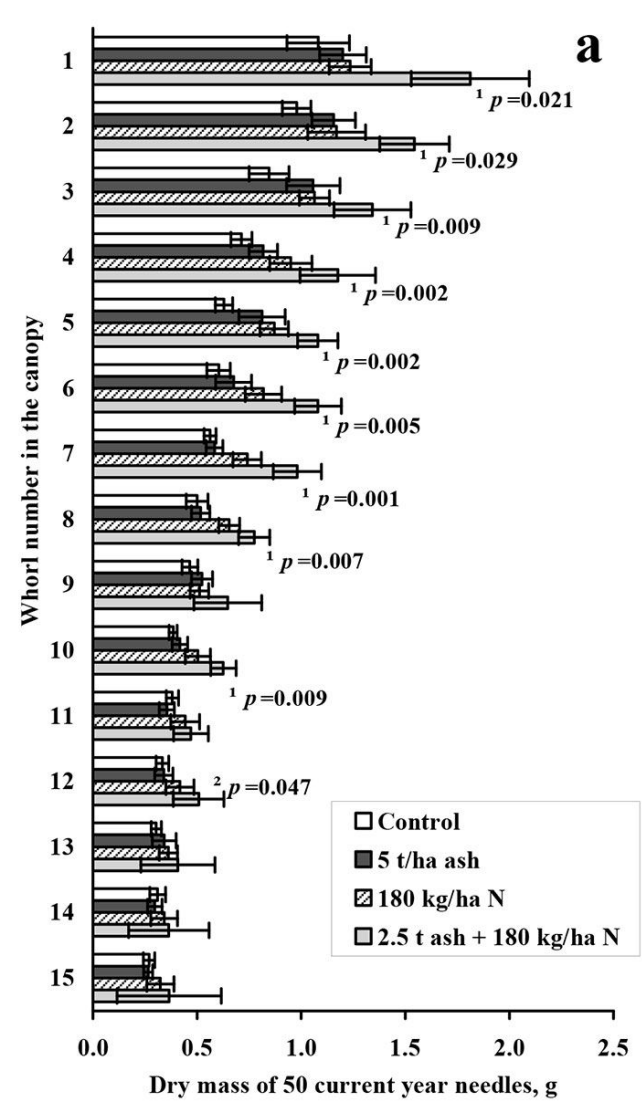

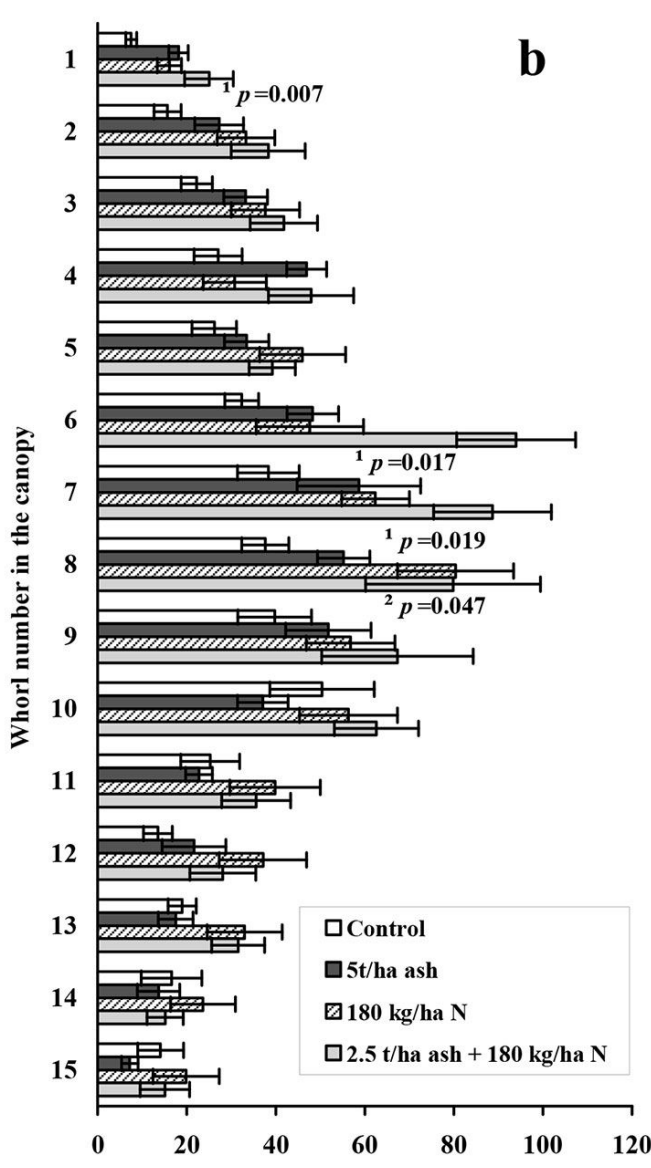

Dry mass of current year shoots, $g$

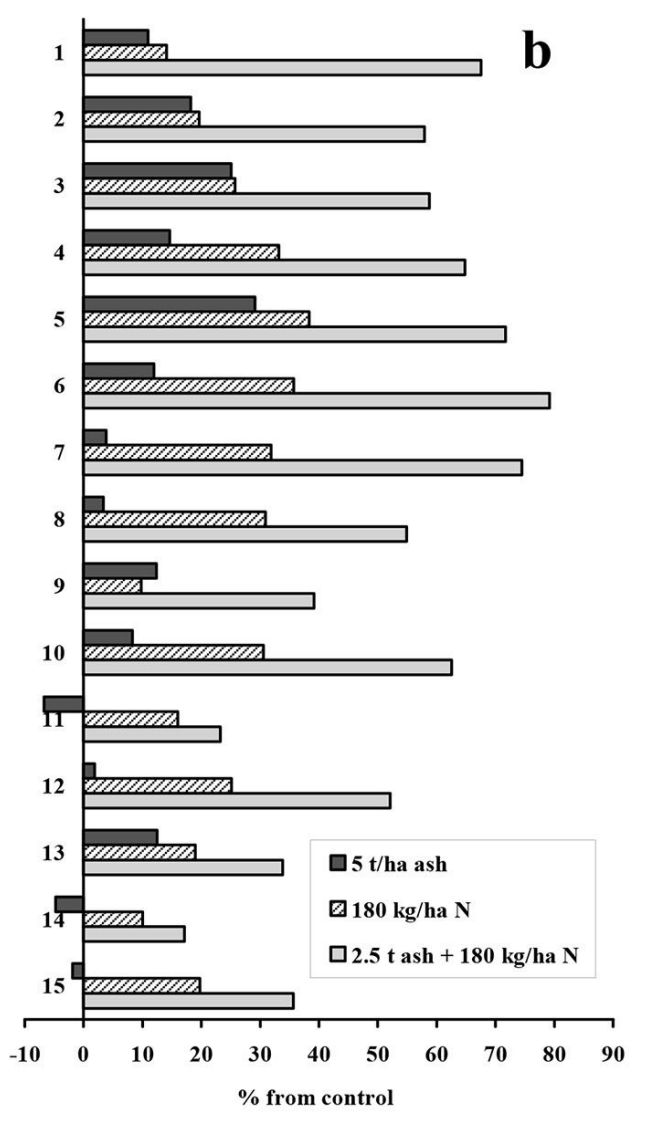

Fig. 1 - Dry mass of current year needles and shoots in different whorls of Scots pine canopy. Mean dry mass of current year needles (a) and shoots (b) in different whorls of Scots pine canopy 2 years after treatment. Error bars show standard error of the mean $(n=9)$. Statistically significant differences of ash plus nitrogen treatment from the control (Kruskal-Wallis ANOVA) are indicated by ${ }^{1}=p<0.05$, statistically significant differences of nitrogen treatment from the control are indicated by ${ }^{2}=p<0.05$.

Fig. 2 - Dry mass of 50 current year needles and differences from control in different whorls. Mean dry mass of 50 current year needles (a) and differences from control data ( $\%$ of control - b) in different whorls of Scots pine canopy 2 years after treatment. Error bars in (a) show standard error of the mean $(n=9)$. Statistically significant differences of ash plus nitrogen treatment from the control (Kruskal-Wallis ANOVA) are indicated by ${ }^{1}=p<0.05$, statistically significant differences of ash plus nitrogen treatment from the ash treatment are indicated by ${ }^{2}=p<0.05$. 
Fig. 3 - Length of mean current year needle in different whorls and differences from the control. Mean length of the current year needle (a) and differences from the control data $(\%$ of control - b) in different whorls of

Scots pine canopy. Error bars in (a) show standard error of the mean

$(n=9)$. Non statistically significant differences (Kruskal-Wallis

ANOVA) between treatments are indicated in all cases at $\mathrm{p}<0.05$.
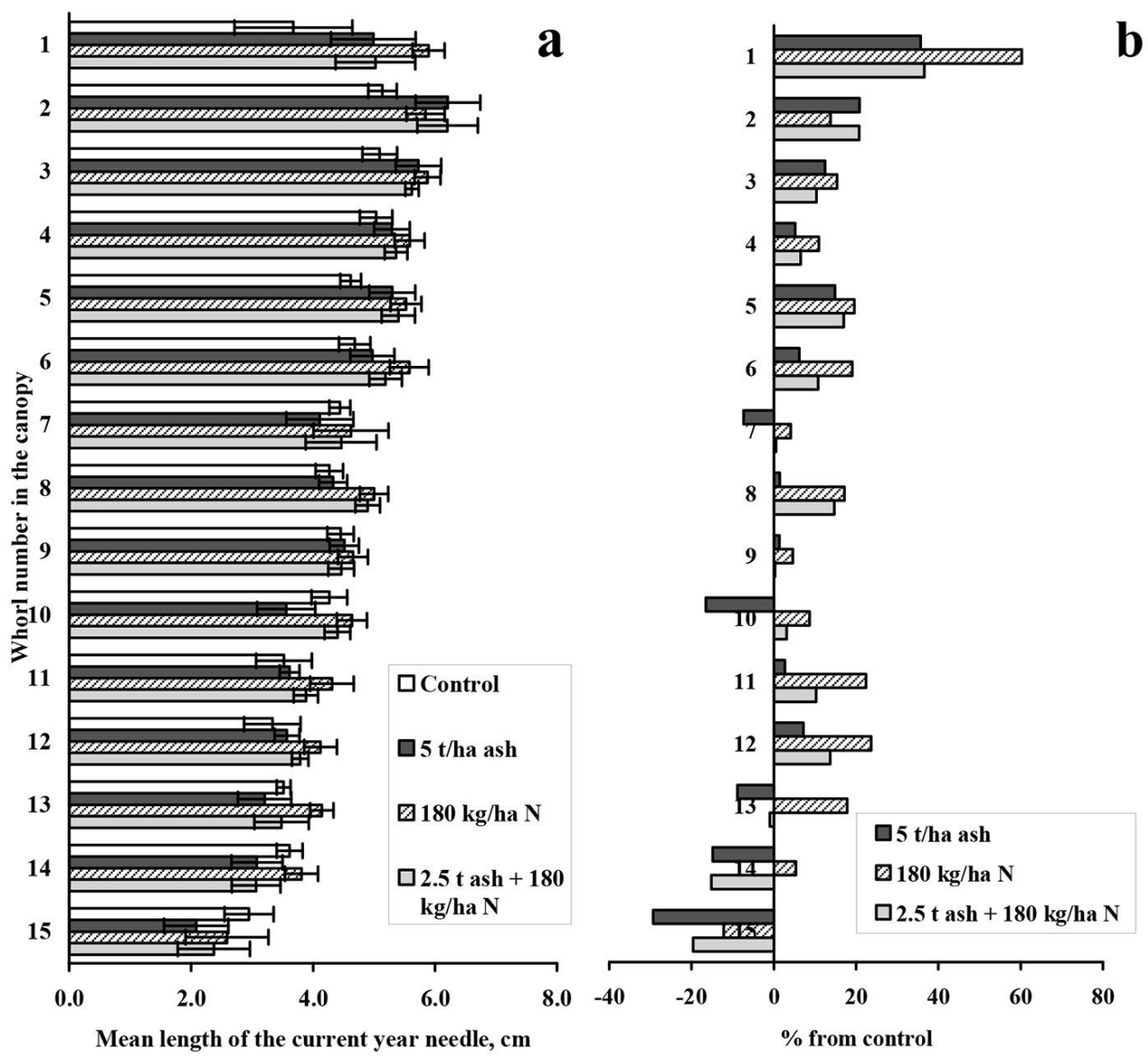

study, the ash and nitrogen effects on needle length were not statistically significant. However, compared with the control, the mean needle lengths increased in response to the treatments in the upper canopy whorls (Fig. 3b).

\section{Responses of various chemical} parameters to different treatments

The differences in nitrogen $(\mathrm{N})$, phosphorus $(\mathrm{P})$, potassium $(\mathrm{K})$, calcium $(\mathrm{Ca})$ and magnesium $(\mathrm{Mg})$ concentrations in the cur- rent-year needles between the treatments were not statistically significant, except for the $\mathrm{N}$ concentration in the $\mathrm{N}$ treatments (Tab. 4). The ratio of the $\mathrm{N}$ concentrations in the current and one-year-old needles changed in response to the nitrogen treatments, i.e., the $\mathrm{N}$ concentration in current-year needles was higher in the treated plots than in the control or ash treatment. This study was unable to demonstrate any increases in the concentrations of $\mathrm{K}, \mathrm{P}$ and $\mathrm{Ca}$ in needles, as is commonly found up to 5 years after ash applications (Arvidsson \& Lundkvist 2002, Jacobson 2003).

In another experiment, $\mathrm{N}$ was treated as a target nutrient in nutrient poor, sandy soils, and the ratios of other nutrients to $\mathrm{N}$ are compared in Tab. 4. In N-treated plots, the nutrient $/ \mathrm{N}$ ratios decreased as the $\mathrm{N}$ concentration increased, to some extent, in the current-year needles. The ratios of various mineral elements in the needles of Scots pine did not show any significant changes compared to the control, except the decrease of the

Tab. 4 - Nutrient concentrations and ratios to N (\%) in current year needles of Scots pine 2 years after treatment. Values are given as the mean \pm SE $(n=3)$. Different letters indicate statistically significant differences (Kruskal-Wallis ANOVA) in the nutrient concentrations between treatments $(\mathrm{p}<0.05)$. $(\dagger)$ : Data was sampled 5 months after the treatment; no comparable data after 2 years is available. $(\$)$ : Knecht $\&$ Göransson (2004).

\begin{tabular}{|c|c|c|c|c|c|c|}
\hline Parameters & Treatment & $\mathbf{N}$ & $\mathbf{P}$ & K & $\mathrm{Ca}$ & Mg \\
\hline $\begin{array}{l}\text { Concentrations } \\
\left(\mathrm{g} \mathrm{kg}^{-1}\right)\end{array}$ & $\begin{array}{l}\text { Control } \\
5 \mathrm{t} \text { ash ha } \\
180 \mathrm{~kg} \mathrm{~N} \mathrm{ha}^{-1} \\
(2.5 \mathrm{t} \text { ash }+180 \mathrm{~kg} \mathrm{~N}) \\
\mathrm{ha}^{-1(\dagger)}\end{array}$ & $\begin{array}{l}13.90 \pm 0.35^{\mathrm{a}} \\
14.43 \pm 0.66^{\mathrm{a}} \\
15.87 \pm 0.48^{\mathrm{b}} \\
16.18 \pm 0.43^{\mathrm{ab}}\end{array}$ & $\begin{array}{l}1.43 \pm 0.03^{\mathrm{a}} \\
1.50 \pm 0.06^{\mathrm{a}} \\
1.57 \pm 0.03^{\mathrm{a}} \\
1.28 \pm 0.09^{\mathrm{a}}\end{array}$ & $\begin{array}{l}4.77 \pm 0.41^{b} \\
4.33 \pm 0.30^{b} \\
3.93 \pm 0.07^{b} \\
3.18 \pm 0.27^{\mathrm{a}}\end{array}$ & $\begin{array}{l}2.23 \pm 0.45^{\mathrm{a}} \\
2.87 \pm 0.12^{\mathrm{a}} \\
2.87 \pm 0.18^{\mathrm{a}} \\
2.46 \pm 0.14^{\mathrm{a}}\end{array}$ & $\begin{array}{l}1.23 \pm 0.12^{\mathrm{a}} \\
1.50 \pm 0.06^{\mathrm{a}} \\
1.30 \pm 0.10^{\mathrm{a}} \\
1.07 \pm 0.03^{\mathrm{a}}\end{array}$ \\
\hline $\begin{array}{l}\text { Nutrient ratio } \\
\text { to } \mathrm{N}(\%)\end{array}$ & $\begin{array}{l}\text { Control } \\
5 \mathrm{t} \text { ash ha } \\
180 \mathrm{~kg} \mathrm{~N} \mathrm{ha}^{-1} \\
(2.5 \mathrm{t} \text { ash }+180 \mathrm{~kg} \mathrm{~N}) \\
\mathrm{ha}^{-1(\dagger)}\end{array}$ & $\begin{array}{l}100 \\
100 \\
100 \\
100\end{array}$ & $\begin{array}{r}10.3^{\mathrm{a}} \\
10.4^{\mathrm{a}} \\
9.9^{\mathrm{a}} \\
8.2^{\mathrm{a}}\end{array}$ & $\begin{array}{l}34.5^{\mathrm{b}} \\
30.3^{\mathrm{ab}} \\
24.9^{\mathrm{ab}} \\
21.0^{\mathrm{a}}\end{array}$ & $\begin{array}{l}15.9^{\mathrm{a}} \\
19.9^{\mathrm{a}} \\
18.1^{\mathrm{a}} \\
14.5^{\mathrm{a}}\end{array}$ & $\begin{array}{c}8.9^{\mathrm{ab}} \\
10.4^{\mathrm{b}} \\
8.2^{\mathrm{ab}} \\
6.6^{\mathrm{a}}\end{array}$ \\
\hline & 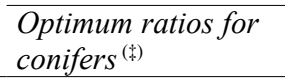 & 100 & $15.0^{\mathrm{a}}$ & 47.5 & 8.0 & 7.5 \\
\hline
\end{tabular}


$\mathrm{K} / \mathrm{N}$ and $\mathrm{Mg} / \mathrm{N}$ ratios in response to the ash plus nitrogen treatment.

\section{Discussion}

Growth and morphometric parameters

Fertilization is one of the important silvicultural practices that can affect both the quantity and distribution of canopy foliage, thereby altering stand growth (Gillespie et al. 1994). Increases in canopy mass and stemwood production following soil nutrient improvements have been reported (Vose \& Allen 1988, Colbert et al. 1990, Gillespie et al. 1994). Nutrient poor, sandy soils are often considered as requiring improvements in nutritious elements, especially if one is aiming to increase tree biomass, e.g., to secure a supply of raw material for the forest industry at a time when the demand for biofuel is increasing (Iivonen et al. 2006, Ozolinčius et al. 2007a, Perucci et al. 2008).

Compensatory biofuel ash fertilization has been recommended for many years in $\mathrm{Li}$ thuania for Scots pine forests growing on Arenosols (Ozolinčius et al. 2011). The aim of the present study was to compare the effects of biofuel ash, nitrogen and ash applied together with nitrogen on dry mass and the concentrations of the main nutrients in different compartments and layers of a Scots pine canopy. Moreover, this paper attempted to clarify the vertical distribution of the aforementioned canopy parameters.

Our results show that the dry mass of the needles and shoots responded less to the application of pure ash and pure nitrogen compared with the ash plus nitrogen treatment. The ash plus nitrogen positively affected these parameters. The current study found that the impact of pure ash became clearer, but not significantly different from the control, when the scale of the analysis was focused on smaller canopy elements, i.e., canopy layers and individual whorls. Generally, fertilization or an increase in the nutrients in soil could be considered as weak factors for stimulating tree growth (Ozolinčius 1998). Our data, to some extent, are comparable to the results obtained by Mandre et al. (2004), who found that the dry masses of foliage and stems could even decrease or remain unaffected after the application of biofuel ash. Gillespie et al. (1994), highlighting crown biomass as a site- and treatment-specific parameter, also observed that fertilization with nitrogen and phosphorus increased foliage biomass. There is a general consensus among scientists that only $\mathrm{N}$ application does not have negative effects on tree growth, except in cases when too much $\mathrm{N}$ is applied. Helmisaari (1998) showed that combined $\mathrm{N}$ and $\mathrm{P}$ fertilization gave a better growth response in nutrient-rich soils than the application of pure nitrogen alone. In contrast, Iivonen et al. (2006) found that the biomass allocation among aboveground organs was not affected by nutrient optimization, except for a reduction in the dead branch proportion.

The results indicated that the upper and middle canopy layers were the tree compartments that were the most sensitive to changes in the soil-nutrient balance, including the addition of pure ash and nitrogen. Unfortunately, these results did not coincide with earlier surveys conducted by Ozolinčius (1998), who showed that fertilization first stimulated shoot growth in the lower part of the crown. At the same time, he referred to other non-specific growth responses, for example, the increase in the increment in the whole crown or in the upper crown compared with the lower part. The reasons for these differences remained unclear and were specific to each site.

Norgren \& Elfving (1994) suggested that the increase in needle biomass could be, to a certain extent, caused by the length and size of individual needles. Generally, increases in tree height and light intensity affect most morphometric parameters, including needle mass and length, which differ between the upper and lower canopies at different intensities (Gebauer et al. 2011).

Despite the fact that the length growth of needles proved to be a good indicator of the effect of pollution in earlier studies (Ots 2002, Ots et al. 2009), the current study found no statistically significant effect of any treatment on length growth.

\section{Nutrient allocation}

Dry mass and the nutrient concentrations in needles have been used as diagnostic tools to infer the nutrient status of trees for a number of years (Finér 1994). Earlier surveys, such as those conducted by Ingestad (1979), Linder (1995) and Knecht \& Göransson (2004), showed that naturally growing plants maintain a relatively constant ratio between $\mathrm{N}$ and other nutrients. As can be seen in Tab. 4, the optimum ratios (Knecht \& Göransson 2004) are relatively lower than values obtained in this study, even in the control plots. We found decreased ratios under the pure $\mathrm{N}$ and ash plus $\mathrm{N}$ treatments, especially for $\mathrm{P} / \mathrm{N}$ and $\mathrm{K} / \mathrm{N}$. We suspect that the increased concentrations of $\mathrm{N}$ caused the imbalanced nutrient proportions in the needles.

In discussing and simultaneously summarizing several studies, Helmisaari (1992) stated that the differences in the needle nutrient concentrations within the canopy were not variable. Most of the analyzed studies focused on nutrient concentrations in relation to biomass changes (Helmisaari 1992, Mandre 2009, Ots et al. 2009, Kuznetsova et al. 2011). We aimed to analyze the needle $\mathrm{N}$ stocks in Scots pine stands to compare the impact of different treatments. The amount of nitrogen in the needles was 1.5 -fold higher in the nitrogen and ash plus nitrogen treatments (124-125 kg ha ${ }^{-1}$ in each) compared with the control $\left(82 \mathrm{~kg} \mathrm{ha}^{-1}\right)$. When analyzing only the current-year foliage, the needle $\mathrm{N}$ stocks in the nitrogen and ash plus nitrogen treatment were $51 \mathrm{~kg} \mathrm{ha}^{-1}$ and $53 \mathrm{~kg}$ $\mathrm{ha}^{-1}$, respectively, which were 1.6-1.7-fold higher than that of the control $\left(32 \mathrm{~kg} \mathrm{ha}^{-1}\right)$. Consistently with other studies (Arvidsson \& Lundkvist 2002, Jacobson 2003, Saarsalmi et al. 2004), the biofuel ash showed no effect on needle $\mathrm{N}$ concentrations. However, the application of $5 \mathrm{tha}^{-1}$ of ash increased the $\mathrm{N}$ stock of the current-year needles by 1.2-fold compared with the control.

The effectiveness of nitrogen was previously discussed by Norgren \& Elfving (1994), Norgren (1996) and Kuznetsova et al. (2011). As stated in the earlier studies, the size of the needles is restricted by their ability to access nitrogen (Norgren \& Elfving 1994). A more efficient use of $\mathrm{N}$ would result in a higher needle biomass. Thus, a higher $\mathrm{N}$ use efficiency is considered to be an advantage on nitrogen-poor sites.

Following this idea, we implied that the pine canopy is able to form larger needles with a lower concentration of nitrogen under the specific nitrogen treatments. The different soil treatments could individually affect the usage of nutrients, thereby inducing the production of the same amount of biomass.

All treatments induced incremental trends in the mass and $\mathrm{N}$ concentration of currentyear needles compared with the control. We assumed that if the ratio between the $\mathrm{N}$ concentration and the dry mass of the currentyear needles was equal to 1 , then both quantitative parameters would change in the same range compared to the control. Our study showed that the mean dry mass of the current-year needles increased more than the $\mathrm{N}$ concentration in all treatments, i.e., Scots pine formed heavier needles with lower levels of nitrogen. The N/dry mass ratio was 0.47 in N-treated plots, 0.27 in ash-treated plots, and 0.33 in ash plus nitrogen-treated plots. These findings further support the idea of higher $\mathrm{N}$ productivity, as the addition of nitrogen caused a 2-fold greater increase in the dry mass compared with the increase in the $\mathrm{N}$ concentration in the current-year needles.

A comparison of the current and one-yearold needles shows that the mass of the current-year needles increased more than the $\mathrm{N}$ concentration in N-treated plots compared with the control (the N/dry mass ratio was 0.41 ). Conversely, the $\mathrm{N}$ concentration increased more than the dry mass in one-yearold needles (the N/dry mass ratio was 1.32 ). We assumed that the new biomass of the current-year needles was produced more effectively per amount of nitrogen compared with the biomass of older needles. However, with a small sample size, caution must be ap- 
plied, and such findings might not be easily compared with other studies.

This study confirmed that the biomass increment could be easily associated with mass allocations in different compartments and layers of the tree; however, the biomass response to the allocation of nitrogen still remains doubtful. These results are consistent with those of other studies (for example, Reekie \& Bazzaz 1987).

\section{Conclusions}

The combination of raw biofuel ash and nitrogen applied on nutrient poor, sandy soils affected the growth of Scots pine during a relatively short period. Such soils were often considered as requiring improvement in nutritious elements, especially if aiming to increase tree biomass.

The approach used in the present study suggests that biofuel ash, nitrogen fertilizers and ash applied along with nitrogen could result in heavier needles in the upper and middle layers of a Scots pine canopy, with a descending trend in needle size as one moves towards the canopy base. It also appears that the ash plus nitrogen treatment gives the strongest significant response $(\mathrm{p}<0.05)$.

All tested treatments of ash and nitrogen resulted in a higher increase in dry mass, but not in length, of the current-year needles compared with the increase in $\mathrm{N}$ concentration. The additional input of nitrogen induced higher increases in dry mass compared with the changes in the $\mathrm{N}$ concentration in the current-year needles. The youngest needles produced more new mass per amount of nitrogen than did older needles.

\section{Acknowledgements}

The original idea of this paper was suggested by Professor R. Ozolinčius who passed away in 2013. The authors thank the colleagues from the Forest Institute for the technical assistance in the field and laboratory. This study was conducted under the FP5 $\mathrm{R} \& \mathrm{D}$ programme "Quality of life and management of living resources" (QLK5-CT-20 01-00527) funded by the European Community, and the long-term research programme "Sustainable forestry and global changes" implemented by the Lithuanian Research Centre for Agriculture and Forestry.

\section{References}

Arvidsson H, Lundkvist H (2002). Needle chemistry in young Norway spruce stands after application of crushed wood ash. Plant and Soil 238: 159-174. - doi: 10.1023/A:1014252521538

Bauer G, Schulye ED, Mund M (1997). Nutrient contents and concentrations in relation to growth of Picea abies and Fagus sylvatica along a European transect. Tree Physiology 17: 777-786. doi: 10.1093/treephys/17.12.777

Bramryd T, Fransman BO (1995). Silvicultural use of wood ashes - effects on the nutrient and heavy metal balance in a pine (Pinus sylvestris L.) forest soil. Water, Air and Soil Pollution 85: 1039-44. - doi: 10.1007/BF00476967

Buivydaite VV, Vaičys M, Juodis J, Motuzas A (2001). Lietuvos dirvožemiu klasifikacija [Classification of soils in Lithuania]. Lietuvos mokslas, Vilnius, Lithuania, pp. 139. [in Lithuanian] Colbert SR, Jokela EJ, Neary DG (1990). Effects of annual fertilization and sustained weed control on dry matter partitioning, leaf area, and growth efficiency of juvenile loblolly and slash pine. Forest Science 36: 995-1014. [online] URL: http://www.ingentaconnect.com/content/ saf/fs/1990/00000036/00000004/art00014

FAO/UN (2006). World reference base for soil resources 2006. FAO, Rome, Italy, pp. 133.

Finér L (1994). Variation in needle nutrient concentrations in the crown of Scots pine on peatland. Silva Fennica 28 (1): 41-51. - doi: 10.142 14/sf.a9161

Gebauer R, Volarík D, Urban J, Børja I, Nagy NE, Eldhuset TD, Krokene P (2011). Effect of thinning on anatomical adaptations of Norway spruce needles. Tree Physiology 31 (10): 11031113. - doi: 10.1093/treephys/tpr081

Gillespie AR, Allen HL, Vose JM (1994). Amount and vertical distribution of foliage of young loblolly pine trees as affected by canopy position and silvicultural treatment. Canadian Journal of Forest Research 24 (7): 1337-1344. - doi: 10.1139/x94-174

Han Q, Kawasaki T, Katahata S, Mukai Y, Chiba $Y$ (2003). Horizontal and vertical variations in photosynthetic capacity in a Pinus densiflora crown in relation to leaf nitrogen allocation and acclimation to irradiance. Tree Physiology 23: 851-857. - doi: 10.1093/treephys/23.12.851

Helmisaari HS (1998). Vitality of trees and forest ecosystems - concepts and criteria. In: "Nutrition and growth of Norway spruce forests in a Nordic climatic and deposition gradient" (Andersson F, Braekke FH, Hallbecken L eds). Nordic Council of Ministers, Copenhagen, Denmark, pp. 212229.

Helmisaari HS (1992). Spatial and age-related variation in nutrient concentrations of Pinus sylvestris needles. Silva Fennica 26 (3): 145-153. - doi: 10.14214/sf.a15643

Iivonen S, Kaakinen S, Jolkkonen A, Vapaavuori E, Linder S (2006). Influence of long-term nutrient optimization on biomass, carbon, and nitrogen acquisition and allocation in Norway spruce. Canadian Journal of Forest Research 36 (6): 1563-1571. - doi: 10.1139/x06-035

Ingestad T (1979). Mineral nutrient requirements of Pinus sylvestris and Picea abies seedlings. Physiologia Plantarum 45 (4): 373-380. - doi: 10.1111/j.1399-3054.1979.tb02599.x

Jacobson S (2003). Addition of stabilized wood ashes to Swedish coniferous stands on mineral soils/effects on stem growth and needle nutrient concentrations. Silva Fennica 37: 437-450. - doi: 10.14214/sf.483

Karltun E, Saarsalmi A, Ingerslev M, Mandre M, Andersson S, Gaitnieks T, Ozolinčius R, Varna-
giryte-Kabasinskiene I (2008). Wood ash recycling - possibilities and risks. In: "Sustainable Use of Forest Biomass for Energy" (Röser D, Asikainen A, Raulund-Rasmussen K, Stupak I eds), Springer, Netherlands, pp. 79-108. - doi: 10.1007/978-1-4020-5054-1 4

Kuznetsova T, Tilk M, Pern H, Lukjanova A, Mandre M (2011). Growth, aboveground biomass, and nutrient concentration of young Scots pine and lodgepole pine in oil shale post-mining landscapes in Estonia. Environmental Monitoring and Assessment 183: 341-350. - doi: 10.1007/s10661-011-1925-x

Knecht MF, Göransson A (2004). Terrestrial plants require nutrients in similar proportions. Tree Physiology 24: 447-460. - doi: 10.1093/ treephys $/ 24.4 .447$

Linder S (1995). Foliar analysis for detecting and correcting nutrient imbalances in forest stands. Ecological Bulletins 44: 178-190. [online] URL: http://www.jstor.org/stable/20113161

Lukjanova A, Mandre M (2009). The effect of wood ash fertilisation on the anatomy and localisation of lignin in Scots pine (Pinus sylvestris L.) needles. Baltic Forestry 15 (2): 177-185. [online] URL: http://www.cabdirect.org/abstracts/20 103057179.html

Lukjanova A, Mandre M (2010). Effects of alkalization of the environment on the anatomy of Scots pine (Pinus sylvestris) needles. Water, Air and Soil Pollution 206 (1-4): 13-22. - doi: 10.1007/s1 1270-009-0080-2

Mäkelä A, Albrektson A (1992). An analysis of the relationship between foliage biomass and crown surface area in Pinus sylvestris in Sweden. Scandinavian Journal of Forest Research 7 (1-4): 297-307. - doi: 10.1080/02827589209382 722

Mandre M (2009). Vertical gradients of mineral elements in Pinus sylvestris crown in alkalised soil. Environmental Monitoring and Assessment 159 (1-4): 111-124. - doi: 10.1007/s10661-0080616-8

Mandre M, Korsjukov R, Ots K (2004). Effects of wood ash application on the biomass distribution and physiological state of Norway spruce seedlings on sandy soils. Plant Soil 265: 301314. - doi: 10.1007/s11104-005-0509-3

Mandre M, Tullus H, Tamm Ü (1998). The partitioning of carbohydrates and biomass of leaves in Populus tremula L. canopy. Trees - Structure and Function 12 (3): 160-166. - doi: 10.1007/ PL00009706

Marcelis LFM, Heuvelink E (2007). Concepts of modelling carbon allocation among plant organs. In "Functional-structural plant modelling in crop production" (Vos J, Marcelis LFM, de Visser PHB, Struik PC, Evers JB eds). Springer, Dordrecht, The Netherlands, pp. 103-111. [online] URL: http://library.wur.nl/ojs/index.php/frontis/ article/viewArticle/1375

Niinemets U, Lukjanova A, Turnbull MH, Sparrow AD (2007). Plasticity in mesophyll volume fraction modulates light-acclimation in needle photosynthesis in two pines. Tree Physiology 27: 1137-1151. - doi: 10.1093/treephys/27.8.1137 
Nilsen P, Abrahamsen G (2003). Scots pine and Norway spruce stands responses to annual N, P and $\mathrm{Mg}$ fertilization. Forest Ecology and Management 174: 221-232. - doi: 10.1016/S03781127(02)00024-5

Norgren O, Elfving B (1994). Needle size and nitrogen concentration of Pinus sylvestris and Pinus contorta. Scandinavian Journal of Forest Research 9: 165-169. - doi: 10.1080/028275894093 82827

Norgren O (1996). Growth analysis of Scots pine and lodgepole pine seedlings. Forest Ecology and Management 86: 15-26. - doi: 10.1016/S03781127(96)03800-5

Ots K (2002). Impact of air pollution on the growth of conifers in the industrial region of Northeast Estonia. PhD thesis, Estonian Agricultural University, Tartu, Estonia, pp. 222.

Ots K, Indriksons A, Varnagiryte-Kabasinskiene I, Mandre K, Kuznetsova T, Klõseiko J, Tilk M, Kõresaar K, Lukjanova A, Kikamegi K (2011). Changes in the canopies of Pinus sylvestris and Picea abies under alkaline dust impact in the industrial region of Northeast Estonia. Forest Ecology and Management 262: 82-87. - doi: 10.1016/j.foreco.2010.07.031

Ots K, Mandre M, Pern H, Kask R, Pikk J (2009). Changes in the allocation of nutrients and biomass in Scots pine (Pinus sylvestris L.) canopy in an area of cement industry in Northeast Estonia. Baltic Forestry 15 (2): 237-247. [online] URL: http://www.balticforestry.mi.lt/bf/PDF_Articles/2009-15[2]/237 247Otsetal.pdf

Ozolinčius (1998). Conifers in Lithuania: transphormations of morphological structure and factors inducing them. Lutute, Kaunas, Lithuania, pp. 300. [in Lithuanian with English summary]

Ozolinčius R, Armolaitis K, Mikšys V, Varnagiryte-Kabašinskiene I (2011). Kompensuojamojo trešimo miško kuro pelenais rekomendacijos [Recommendations for compensating wood ash fertilization]. Ministry of Environment of the Republic of Lithuania/Institute of Forestry of Lithuanian Research Centre for Agriculture and Forestry, Kaunas-Girionys, Lithuania, pp. 17. [in Lithuanian with English summary]
Ozolinčius R, Varnagiryte-Kabašinskiene I, Armolaitis K (2010). Compensations of nutrients removed through extraction of forest fuel. In: "Contraction for a Sustainable Environment" (Sarsby RW, Meggyes T eds.). Taylor \& Francis Group, London, UK, pp. 493-500.

Ozolinčius R, Buožyte R, Varnagiryte-Kabašinskiene I (2007a). Wood ash and nitrogen influence on ground vegetation cover and chemical composition. Biomass and Bioenergy 31: 710716. - doi: 10.1016/j.biombioe.2007.06.015

Ozolinčius R, Varnagiryte-Kabašinskiene I, Armolaitis K, Gaitnieks T, Buožyte R, Raguotis A, Skuodiene L, Aleinikoviene J, Stakenas V (2007b). Short term effects of compensatory wood ash fertilization on soil, ground vegetation and tree foliage in scots pine stands. Baltic Forestry 13: 158-168. [online] URL: http:// www.balticforestry.mi.lt/bf/index.php?id=127\& Itemid $=101$

Ozolinčius R, Varnagiryte-Kabašinskiene I, Stakenas V, Mikšys V (2007c). Effects of wood ash and nitrogen fertilization on Scots pine crown biomass. Biomass and Bioenergy 31: 700-709. doi: 10.1016/j.biombioe.2007.06.016

Pearcy RW, Sims DA (1994). Photosynthetic acclimation to changing light environments: Scaling from the leaf to the whole plant. In: "Exploitation of environmental heterogeneity by plants: Ecophysiological processes above and below ground" (Caldwell MM, Pearcy RW eds). Academic Press, San Diego, CA, USA, pp. 145174. [online] URL: http://books.google.com/ books?id=59Tp1uI99foC

Perucci P, Monaci E, Onofri A, Vischetti C, Casucci C (2008). Changes in physico-chemical and biochemical parameters of soil following addition of wood ash: a field experiment. European Journal of Agronomy 28: 155-161 - doi: 10.1016/j.eja.2007.06.005

Rautio P, Fürst A, Stefan K, Raitio H, Bartels U (2010). Sampling and analysis of needles and leaves. Manual part XII. In: "Manual on methods and criteria for harmonized sampling, assessment, monitoring and analysis of the effects of air pollution on forests". UNECE, ICP Forests
Programme Co-ordinating Centre, Hamburg, Germany, pp. 19. [online] URL: http://www.icpforests.org/Manual.htm

Reekie EG, Bazzaz FA (1987). Reproductive effort in plants. 2. Does carbon reflect the allocation of other resources? American Naturalist 129: 897-906. - doi: 10.1086/284682

Richardson AD, Ashton PMS, Berlyn GP, McGroddy ME, Cameron IR (2001). Withincrown foliar plasticity of western helmlock, Tsuga heterophylla, in relation to stand age. Annals of Botany 88: 1007-1015. - doi: 10.1006/anbo.20 01.1538

Rumpf S, Ludwig B, Mindrup M (2001). Effect of wood ash on soil chemistry of a pine stand in Northern Germany. Journal of Plant Nutrition and Soil Science 164: 569-575. - doi: 10.1002/ 1522-2624(200110)164:5<569::AID-JPLN569> 3.0.CO;2-E

Saarsalmi A, Melkönen E, Kukkola M (2004). Effect of wood ash fertilization on soil chemical properties and stand nutrient status and growth of some coniferous stands in Finland. Scandinavian Journal of Forest Research 19 (3): 217-233. - doi: 10.1080/02827580410024124

Saarsalmi A, Melkönen E, Piïrainen S (2001). Effects of wood ash fertilization on forest soil chemical properties. Silva Fennica 35 (3): 355 368. - doi: 10.14214/sf.590

Vaičys M, Karazija S, Kuliešis A, Rutkauskas A (2006). Mišku augavietes. Miško augaviečiu tipai [Forest sites. Forest site types]. Lutute, Kaunas, Lithuania, pp. 95. [in Lithuanian] Varnagiryte-Kabašinskiene I (2008). Complex study of foliage nutrient status in ash fertilized Scots pine stands in Lithuania. Journal of Forest Science 54: 195-206. [online] URL: http:// www.agriculturejournals.cz/publicFiles/01340.p df

Vose JM, Allen HL (1988). Leaf area, stemwood growth, and nutrition relationships in Loblolly Pine. Forest Science 34: 547-563. [online] URL: http://www.ingentaconnect.com/content/saf/fs/1 988/00000034/00000003/art00003 